\title{
Spiritualised political theology in a polarised political environment: A Pentecostal movement's response to party politics in Zimbabwe
}

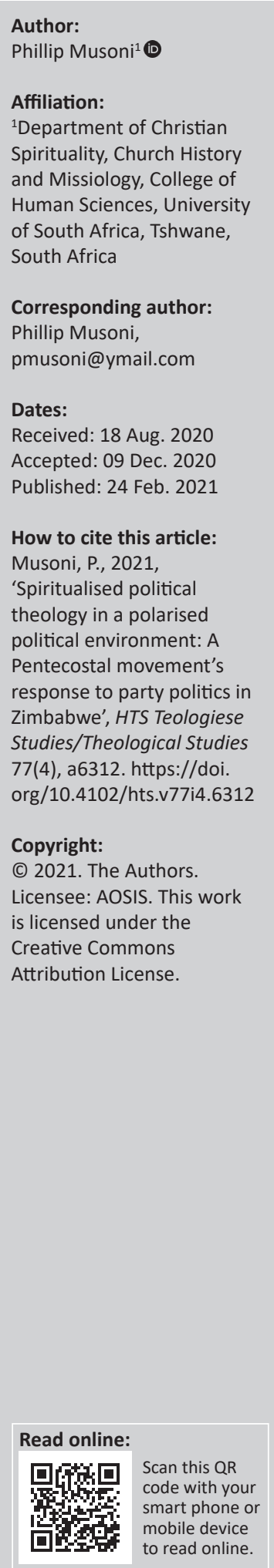

This article interrogates the interface between the older Pentecostal movement and politics in Zimbabwe. The country continues to face political violence and a breakdown in rule of law. The Zimbabwean populace is asking whether the Zimbabwean Pentecostal movement is ready and able to exercise its prophetic role in promoting real peace and democracy. Many Zimbabweans are asking this question, because the track record shows that whilst most mainline churches have been consistent in becoming the voice of the voiceless, some Zimbabwean Pentecostal churches seem to have been sitting on the fence for too long by adopting a middle of the road stance, thereby avoiding a head-on confrontation with the corrupt Zimbabwe African National Union-Patriotic Front (ZANU-PF) government. In this article, I argue that for many decades the Zimbabwean Pentecostal movement has taken what one might refer to ironically as a 'smart approach to politics'-in which the image of the ZANUPF government is sanitised by espousing what I call a 'spiritualised political theology.' I use this critique, whilst remaining cognisant of the fact that the primary motivation of the movement on which I focus in this article, was evangelism, not politics. Thus, for the purpose of this research, the Zimbabwe Assemblies of God Africa (ZAOGA) of Apostle Ezekiel Guti was sampled to investigate its prophetic voice in a polarised political environment. This article examines the history of Apostle Guti's political subterfuge based on the reflections of his pastoral letters referred to as the 'Ten-days prayer letters' issued since 1975 up to the time of writing this article. It is important at this early stage to outline that these letters were not political statements or meant to address politics only but theological letters addressing different social ills including politics. Thus, reading this letter one shall see that Apostle's political subterfuge demonstrated a continuous oscillation of a theological position on how the church should relate to politics. Furthermore, I undertake a brief examination of other few millennial Zimbabwean Pentecostal churches to see if this political subterfuge transcended elsewhere thereby propagating a spiritualised political theology.

Contribution: What is key to note is the fact that the Zimbabwean Pentecostal movement remained insignificant with regard to democratization agenda even after the removal of President Mugabe. The above claim is evidenced by the Zimbabwean Pentecostal church founders' continuous political subterfuge authenticated by a propagation of a spiritualized political theology.

Keywords: party politics; political subterfuge; spiritualised political theology; old Zimbabwean Pentecostal movement; ZAOGA.

\section{Introduction}

Research on Zimbabwean Pentecostalism and church founders' political subterfuge continues to proliferate. Maxwell (2006), Togarasei (2006), Biri (2013) and Chitando (2013) have described how the Zimbabwean older Pentecostal movement compromised its prophetic role, by failing to reprimand the ZANU-PF government when its officials were involved in political violence and corruption. The cited scholars postulate that the main reason why most Zimbabwean Pentecostal churches find it difficult to highlight the misdeeds of the ZANU-PF government was their propagation of what this article referred to as a problematic 'spiritualised political theology'. 'Spiritualised political theology' as a term is used in this study to refer to a situation where Pentecostal church founders encourage their church members to pray as the only weapon for peace in a polarised political environment. Besides, spiritualised political theology is where Pentecostal church founders distance their church members from engaging in politics since politics is seen as a dirty game. As conflicting, spiritualised political theology as a term is also used in this article to 
refer to a situation where Pentecostal church leaders preach that governments are elected and ordained by God, hence, anyone criticising government officials will be punished by God. Such theology is mostly drawn from Pentecostals' literal understanding of (Rm 13:1) and (1 Tm 2:1-2). Romans 13:1 reads 'Let everyone be subject to the governing authorities, for there is no authority except that which God has established. The authorities that exist have been established by God. (NIV)'. In turn, I Timothy 2:1-2 reads- First of all, then, I urge that supplications, prayers, intercessions, and thanksgivings be made for all people. For kings and all who are in high positions, that we may lead a peaceful and quiet life, godly and dignified in every way (ESV).

This article argues that the above-cited scriptures are the base for Apostle Guti' spiritualised political theology as they dominate in his Ten-day prayer letters. These Ten-days letters are located into three dispensations, (1975-1989), (1990-1999) and (2000-2020). Thus, as guided by the literal understanding of Romans 13:1 and 1 Timothy 2:1-2 Apostle Guti has religiously set aside the first prayer point of these letters to pray for the State President, solders, judges and the police force. A careful study of this prayer point has shown that in each dispensation, Apostle Guti rephrased this prayer point a political subterfuge in a polarised political environment in Zimbabwe.

The first dispensation (1975-1989) covers the colonial era and the early years of Zimbabwe's political independence. The second dispensation that stretched from 1990 to 1999 is characterised by an uncontested ZANU-PF government (a political environment where ZANU-PF had no strong opposition party to challenge its misgivings). Furthermore, the third dispensation is characterised by the emergence of a political party, which became a thorn in the flesh for the ruling ZANU-PF. The rise of the late Morgan Tsvangirai with his Movement for Democratic Change (MDC) formation in 1999 had a considerable impact on the political landscape in Zimbabwe. From 2000 to 2020, we see this third dispensation was characterised by a great deal of political brutality by the ZANU-PF. Thus, studying Apostle Guti's pastoral letters in these three political dispensations will help us understand the Church's tactics in trying to manage the Church and politics in Zimbabwe over the years.

\section{Methodology}

This article studies the older Zimbabwean Pentecostal movement's responses to politics: a reflection of Apostle Guti's annual Ten-days prayer letters. I decided to discuss the Ten-days prayer letters to investigate Apostle Guti's understanding of the Church and politics in Zimbabwe. The reason for this submission is that the Ten-days prayer letters constitute Apostle Guti's irrevocable theological statement regarding his Church. Thus, whilst Apostle Guti is writing only to his church members and not to the general public, one can still use the letters to deduce Apostle Guti's theological framework on the Church and politics in Zimbabwe. Therefore, I consider the Ten-days prayer letters to be extremely useful and credible as rudimentary sources that theologians can use to construct Apostle Guti's theology on Church and politics; particularly, when one looks at the language and style in which these letters were written, one would notice that for the three political dispensations presented in this article, Apostle Guti used different writing styles and approaches to politics. Accordingly, this research is mainly based on the ZOAGA Ten-days letters and other books written by Apostle Guti. In addition to the Ten-days prayer letters and Apostle Guti's books, a few selected senior church members were interviewed to substantiate the importance of these letters for the church. Above all, other academic sources were also consulted to support the hypothesis of this study.

\section{Prophetic voice: A definition}

Revisiting the definition of terms, particularly with regard to the subject of the Zimbabwean Pentecostalism and politics seems to be an unnecessary repetition. However, the reason why this section discusses the key phrase 'prophetic voice' is that over a decade now, Zimbabwe has experienced a mushrooming of acclaimed prophetic churches. Thus, revisiting the phrase 'prophetic voice' is necessary because one must outline which theological perspective one is adopting to underpin a prophetic voice, particularly in a politically polarised environment. Therefore, the researcher has used the lens of both the Old Testament and New Testament, to underpin the discourse on a prophetic voice in a polarised political space.

In the Old Testament, a prophet is one who has been called by God and is filled with God's spirit to share God's word with people who have distanced themselves from God in one way or another (Vengeyi 2010:11). In one sense, a prophet is often a whistle-blower, particularly, when an entire tribe or nation has turned away from God (Gunda 2014:23). An example of an Old Testament prophet is Moses, who was used by God to:

Rescue the Hebrew people from slavery in Egypt and then to lead them to the land God had promised them. In the Old Testament history books (Joshua, Judges, 1 \& 2 Samuel, 1 \& 2 Kings, 1 \& 2 Chronicles, Ezra, and Nehemiah), prophets such as Deborah, Samuel, Nathan, Elijah, Elisha, Huldah, were raised by God to be the voice of the voiceless. (Gunda 2014:55)

Initially, Israel's religious worship was organised around the labour 'of priests, first in the tabernacle and later in the temple (Vengeyi 2013:30). The day-to-day job description of priests lay in slaughtering, butchering and roasting the sacrificial animals brought by worshipers' (Gunda 2014:56). However, a priest's tasks extended beyond the heavy physical work of dealing with thousands of animal sacrifices. A priest was also responsible for being:

$[A]$ spiritual and moral guide to the people. Whilst the priest was often seen primarily as the mediator between the people and God in the temple sacrifices, his larger duty was to teach God's law to the people (Lev. 10:11; Deut. 17:8-10; 33:10; Ezra 7:10). (Vengeyi 2010:5) 
In Israel's history, however, the priests themselves often became corrupt and turned away from God and led the people in the worship of idols (Gunda 2014:55). It is against this background that the office of the prophet emerged to provide some checks and balances with regard to the corrupt priests, kings and judges who had failed to govern the country justly (Vengeyi 2010). In a sense, God called and spoke through prophets who acted as whistle-blowers when the whole Israelite enterprise was on the brink of self-destruction (Gunda 2014:55).

In the New Testament tradition, Kgatle (2018:1) cites Nell (2009:565) who defines a prophet as one who preaches, hence, a prophetic voice becomes a form of preaching, which addresses socio-economic and political issues. This definition concurs with the Old Testament's tradition in the sense that a prophet, as a preacher, is the voice of God to God's people at all times and in all situations. Thus, the question raised, therefore, throughout this study is: To what extent has Apostle Guti addressed the socio-economic and political issues through his Ten-days prayer letter and in his other writings? Alternatively, to what extent have the Zimbabwean Pentecostal Church founders sacrificed their lives and drawn attention to the wrongdoings of the ZANU-PF government for the improvement of the lives of the ordinary citizens? These questions are raised because the Bible has accounts where prophets of God denounced the kings of their time. In many instances, in his preaching, Jesus rebuked the rulers and rich people who ignored the voices and the plights of the ordinary citizens (Mt 3:7; Mt 16:1-5; Mk;2; Lk 16:19-31; 18:1-8). These passages are examples where in his preaching, Jesus addressed the issues of corruption. Not only did Jesus address corruption but also promised that justice would someday come to the entire broken system that perpetuates injustice (Mk 13:2).

Thus, the prophets / preachers of the Old and New Testaments are called by God to be God's mouthpiece, to rebuke evildoers, to be the voice of the voiceless and to prepare people for eternal life in heaven. The question is: Is this what we see with the Zimbabwean Pentecostal movement?

\section{A Pentecostal movement's response to party politics in Zimbabwe}

The Assemblies of God Africa (AOGA) was established in 1960 (Guti 2014:10), although Maxwell (2006) argues that it was formed in 1968 (p. 60). After independence in 1980, the church was renamed the Zimbabwe Assemblies of God Africa (ZAOGA). The church continued to expand and set up branches in all the provinces of the country. Perhaps as a result of ZAOGA having branches in all provinces of the country, Apostle Guti introduced the writing of Pastoral letters in order for him to be able to reach out for his churches in all provinces. Whilst the letters are referred to as the Tendays letters, this study argues that the letters are more than just prayer letters but Apostle Guti's way of pastoring his Church that had spread to all provinces of the country. This is so because in the interviews one senior Pastor of this Church whose name remained anonymous argued that upon receiving the letters church members would preach from the sameletter throughout the wholeyear (interview:11/04/2020).

Therefore, the significance of these Ten-days letters to ZAOGA members can be equated to the Roman Catholic Pope' three annual addresses, that is, Easter, Christmas and end of the year. Similar to the Pope's delivery speeches, the Ten-day prayer letters presents Apostle Guti's theology, which then constitutes the theology of the church at large. The importance of these letters can be seen in the fact that throughout the year, ZAOGA members will interpret events in reference to the content of these letters, making them appear as already revealed to the church founder when the year began.

\section{The church's response to politics (1975-1989)}

The first set of the Ten-days letters discussed in this article is the set of 1975-1989. The period of 1975-1989 marks the beginning of a troubling time for Apostle Guti's church and the Zimbabwean populace in particular. For instance, during this period, Apostle Guti's church as an African indigenous church was seen by the white colonial government as being aligned to the nationalist movement. Yet, on the other hand, the nationalist movement was not sure of the church's agenda. It is during this troubling time, that Apostle Guti's evangelistic tent meetings in the Highfield and Harare Mbare townships were targets for fire-bombing by the nationalist movement (Maxwell 2006:64). In 1977, 2 years later, after the Apostle had introduced the writing of the Ten-day letters, the following extracts were extracted from his letters:

Let's pray for 1977, it's not a good year. We need God to fight for us ...

In 1980 ... 'Let's pray for the year of miracles ...'

In 1981 and 1982 ... 'Thanking God for answering our prayers ...'

(Extracts from Guti's Ten-day prayer letters)

The above-mentioned letters were randomly selected because Apostle Guti repeatedly used the same phrase throughout his writings under the period reviewed. In all his letters during this dispensation, Apostle Guti religious called his members to pray to God so that each year would be a good year and for God to fight for people. In doing so, we see a spiritualised political theology. It is a spiritualised political theology because instead of confronting the party leaders who were persecuting the Zimbabwean citizen, Apostle Guti called his members to pray. In 1980, Apostle Guti's Ten-days letter was to encourage his church members to pray for a year of miracles. In 1982, Apostle Guti, through his writings, encouraged his church members to thank God who had heard them. Thus, for Apostle Guti, the Church cannot engage in politics by confronting the political party leaders for their evil activities. Thus, Apostle Guti' spiritualised political theology sees the destruction of his tents and persecution of citizens during the war times as the works of the devil, not the government officials of that time. A senior 
member of this Church intimated to the researcher during research saying:

‘[D]uring such difficult times, Baba Guti would gather us to encourage us to pray. In such times Baba Guti would always repeat these words 'let the devil do his work and us doing our work.' (Interview: Participant 1, Senior Church member, 77 years, male 20/03/2020)

In 1983, the worst calamity ever struck the country. President Mugabe who did not want any other political party except his ZANU deployed soldiers to go and kill the Ndebele people who were the main supporters of the Zimbabwe African People's Union (ZAPU) apparel liberation movement. To achieve his ambition of having a one-party state, Mugabe deployed his soldiers to Matabeleland under the pretext of eradicating dissidence, although his ulterior motive was to extinguish ZAPU. Thus, in 1983 the government deployed the Fifth Brigade to Matabeleland. At their passing-out parade, 'Prime Minister Mugabe handed over the brigade flag, inscribed "Gukurahundi," to the then late Colonel Perrance Shiri, the first commander of the Fifth Brigade ${ }^{1}$. He then instructed them to 'plough and reconstruct' (Catholics in Coalition for Justice and Peace [CCJP] 1997:47). By using the phrase 'ploughing and reconstructing', Mugabe was actually instructing Perrance Shiri to go and kill all people found in ${ }^{1}$ the Matabeleland (Gundani, 2008). Various scholars have already written about this era and have shown that it was characterised by the most heartless form of unrestrained power and total disregard for human dignity.

Again, during such periods of gross political violence which resulted in the massacre of many innocent Ndebele people, by Mugabe and his ZANU, this Zimbabwean Pentecostal movement amongst other Old Zimbabwean Pentecostal churches of that time, did not utter a word against Mugabe and his ZANLA. Instead, Apostle Guti wrote to his church members:

... Let's pray for the fear of God in the hearts of the believers. Church members must be holy and steadfast without being moved by what is happening. Pray that Christians become ready for the second coming of Jesus Christ (Extract from Guti's Ten days prayer letters 1985 Ten days prayer letter, p. 1).

Encouraging members to be steadfast without being moved by what was happening is, therefore, described in this article as the propagation of a spiritualised political theology. For him, the Church has nothing to do with politics. Thus, it is the view of this author that spiritualised political theology resulted in Pentecostal churches of that time to not address the root causes of political problems. For this reason, Maxwell (2000:256) describes the silence towards political violence by the African Pentecostal movement as a sign of sectarian tendencies. Sectarianism as the term was used to describe movements that see themselves as aliens to this world and have nothing to do with the world (Hallencreutz 1988:87).

\footnotetext{
1.Perrance Shiri by the time of his death was the Agriculture Minister of Zimbabwe. Shiri is reported to be the first senior government official to succumb to the COVID-19 pandemic. He died at the age of 65 . https://www.news24.com/news24/ COVID-19 pandemic. He died at the age of 65 . https://wwW.news24.com/news $24 /$
africa/news/zimbabwe-minister-perrance-shiri-died-of-covid-19-mnangagwasays-20200730-2.
}

Thus, for Maxwell (2000:256), Apostle Guti in his early days discouraged his church members from participating in social gatherings, such as attending political gatherings and going to the cinema, amongst other social activities describing such activities as of 'this world'.

Perhaps this is the reason why, Apostle Guti focused in his letters on encouraging his members to continue preaching the gospel that delivers people from alcohol and sexual immorality, for example, so that when people die, they go to heaven. This suggests that this Zimbabwean Pentecostal movement maintained its theological position of being apolitical. I argue that from the destruction of his church tents to the killing of people during Operation Gukurahundi, Apostle Guti continued to encourage his members to live a holy life in order to qualify for eternal life. However, Togarasei argued that African Pentecostal churches must realise that the Church is as earthly as it is concerned about being heavenly (Togarasei 2013:106). Furthermore, Togarasei opined that Pentecostal churches should remember the "words of the Lord's prayer (Let your kingdom come, let it be done on earth as it is in heaven') Matthew 6:10 and to act to bring the kingdom of God on earth" (Togarasei 2013:106). However, this position did not continue for long, leading us to the second dispensation.

\section{The church's response to politics (1990-1999)}

Apostle Guti's political orientation shifted with the dawn of the 1990-1999 period, which marks the second dispensation. As quoted by Maxwell (2006), Apostle Guti raised the following new theological arguments on the Church's involvement in developments:

We used to preach rapture. Oh yes, we used to say the Church will be caught up before the tribulations, but I don't preach it again in this country, but in America, they are still saying that the Church will be caught before tribulations, but in Africa, we no longer say that, why? Because we went through some tribulations. Our people were hung in trees and burnt alive. Others were forced to kill their parents. Some of the tribulations we read in the Bible have seen them in Africa. (p. 143)

Again, it was during this second phase that Apostle Guti (1994) shifted his focus from just preaching alone without being involved in public affairs:

Preaching alone without involvement in the development of the nation, it can only help spiritually, but people are living in poverty. That is why the politicians are not worried about the indigenous churches ... The problem of indigenous churches is that they lack influential power to influence nations. Therefore, indigenous churches should look at life in a much broader horizon than to only think of future blessings ... preaching alone without participating in the development of a nation can only help spiritually, while people live in poverty without financial resources to spread the gospel. That is why politicians are not bothered about indigenous churches because they do not have a realistic approach. (pp. 44, 64)

Based on the given citations, it is the author's view that the shift from non-involvement in political issues to involvement 
in politics was necessitated by a number of factors. Firstly, the church was growing and needed the support of the present government to get land for church buildings. Besides, during the early 1990s, ZANU-PF was being celebrated for being the revolutionary party that brought independence. It is an undisputed fact that at one point in time Mugabe was a celebrity in the history of Zimbabwe. Accordingly, this first quarter of 1990 represents a situation in Zimbabwe that can be equated to the New Testament pax Romana [peace in Rome]. Unfortunately, in the late 1990s, ZANU-PF misused the trust, resulting in many government officials being involved in many scandals, during which time, the corrupt activities of politicians increased. The looting of resources by government officials escalated. One example that can be cited is that in 1997 there was the pay-out of $Z \$ 50000.00$ to each former freedom fighter, which led to the economic fortunes of Zimbabwe being impacted extremely negatively (Gunda \& Mtetwa 2013:164). This was the climax of ZANU-PF's corruption under the then President Mugabe (Gunda \& Mtetwa 2013:164). It is such looting of state resources that saw ZANU-PF again losing the support of older historic mission churches. Thus, for the second time, the Catholic Commission for Justice and Peace was the leading organ to protest against corruption and advocating accountability (Maxwell 2006:146). However, as Mainline churches distanced themselves from supporting the ZANU-PF government, the Zimbabwean Pentecostal movement's leadership seized the opportunity to make friends with the ZANU-PF government (Maxwell 2006:147). In accordance with this, the Ten-days prayer letters of ZAOGA adopted a different tone with regard to the ZANU-PF government. Upon reading these pastoral letters from that period, one finds that a new paragraph has been inserted:

Praying for our President Comrade Robert Gabriel Mugabe and his government. Praying for the police and soldiers for this is what was commanded by God that - 'first of all, partitions prayers, intercession and thanksgivings be made for all people, for Kings and all those in authority, that we may live peaceful and quiet lives in all godliness and holiness' (1 Tm 2:1-2 KJV). (Extract from Ten days letter prayer of 1990 ten days prayer letter, p.1)

One could ask what prompted the movement to make these drastic changes, from being apolitical, to being so concerned with public affairs and requesting church members to pray for President Mugabe and his government? Why was it so important now to pray for a government from which the Church had distanced itself for a long time and had refrained from referring it to as of the 'this world?' As argued elsewhere in the article, Apostle Guti's political engagement changes because he has an immediate problem with regard to establishing a modus operand $i$ with a new regime that guarded its legitimacy jealously. The church had grown and could not continue to gather in classrooms for church services. More land was needed to build more church buildings. Thus, singing praise songs for ZANU-PF by the Zimbabwean Pentecostal movement was perhaps the church' strategy to position itself to find favour in the eyes of the ruling ZANU-PF government. I argued that, praying for the President and his government was the Church's way of safeguarding its future under a ruthless ZANU-PF government.

It was this mutual relationship between the ZAOGA Church and ZANU-PF that saw Mugabe and some ZANU-PF top officials being invited to attend the ZAOGA Church meetings (Biri 2013). One of Mugabe's first formal campaign engagements entailed a meeting with Pentecostal leaders involved in the Benny Hinn Healing Crusade, a meeting that was controlled by ZAOGA and was convened at the ZANU-PF headquarters. The venue itself was an indication of a mutual relationship between the church and ZANU-PF. For Maxwell through these reciprocal relations between the church and the ZANU-PF leadership, ZAOGA was able to enhance its primary objective of evangelism without any disruption (Maxwell 2006:112). Therefore, this article opines that praying for Mugabe and his government was the church's propagation of a spiritualised political theology, signifying an ingenious plan to avoid a head-on confrontation with the ZANU-PF government. This article argues that Apostle Guti deliberately chose to sacrifice his prophetic voice in order to gain favour in the eyes of the King (Mugabe) and be granted the fulfilment of his petitions (land to build more centres of worship).

Apostle Guti did not stop at commanding his church members to pray for Mugabe. In fact, Apostle Guti (1994) went on to seek favour with ZANU-PF by mobilising his church members to attend political gatherings and even participate in politics:

Why do we not have more born again Christians participating in the running of the country? I believe that a good Christian should participate in the running of the government, but how can you do so if you do not attend political meetings? I say a good Christian, not only a Christian, but a true one, should be involved in the ruling of the nation, because a true Christian will never deviate from the truth that he received from Christ. Being involved in national affairs will never change his character, he will remain an all-weather Christian. (p. 33)

In echoing Togarasei, perhaps the church had realised that there is no distinction between the natural and supernatural, between heaven and earth (Togarasei 2013:106). Besides, the church had perhaps also learnt that distancing itself from national affairs would thwart all opportunities to acquire material resources. In singing songs in praise of the ZANU-PF government, Apostle Guti (1994) wrote:

Today people have no fear of God, and they do not respect their leadership, hence, the problems amongst the nations. In Romans 13:1-7, it says, "Let every soul be subject to the governing authorities. For there is no authority except from God, and the authorities that exist are appointed by God." Therefore, whoever resists the authority resists the ordinance of God, and those resists will bring judgment on themselves. (p. 46)

However, with the rise of inflation, unemployment soaring and political violence that has resulted in millions of citizens fleeing into political exile, Apostle Guti's approach to Church and politics changed. 


\section{The church's response to politics (2000-2020)}

At the dawn of 2000-2020, which is the last epoch covered in this article, ZAOGA's leadership was quick to shift from its open support of the ZANU-PF government. As ZANU-PF's legitimacy grew ever more tenuous and resorted to more political violence to stave off its opposition the MDC, ZAOGA's relationship with ZANU-PF became shaky. Given that the bulk of its membership in the townships was terrorised by a coalition of war veterans, police and the army who saw them as potential MDC supporters, ZAOGA could not ignore their voices. From 2000 to 2020, Apostle Guti decided to delete the phrase "Praying for our President Robert Gabriel Mugabe and praying for our soldiers and police." Apostle Guti, removed that phrase 'Praying for President Robert Gabriel Mugabe' but reinstated the phrase: 'praying for our country so that God may have mercy on us' (extract from the Ten days letters of 2000-2020) (Guti 2015:19).

This article argues that Apostle Guti deliberately removed the phrase, 'praying for the President, Robert Mugabe', in his letters, from 2000 onwards, even though the late Mugabe was still the Zimbabwean president. Instead, Apostle Guti simply says: 'Let's pray for our country Zimbabwe so that God may have mercy on us'. This article argues that Apostle Guti deliberately decided to edit his Ten-days letters by removing the phrase 'pray for President Robert Mugabe' to maintain his political camouflage. Praying for President Mugabe would indicate an open support of Mugabe who had caused much suffering to the ordinary masses. Thus, to mention Mugabe in his prayer letters during this time, would imply that Apostle Guti openly supported ZANU-PF and not the Movement for Democratic Change (MDC). Furthermore, in doing that, Apostle Guti would lose a sizeable number of youthful members who constitute the majority of his urban church membership as discussed elsewhere in this article. Thus, this article argues that by removing the phrase 'pray for Mugabe' Apostle Guti was playing politics and resorted to setting an agenda.

In 2002, a ZAOGA Church member was quoted by the researcher saying:

'Haa ini kana Tsamba yema Ten days ikati namatirai Mugabe ne Hurumende yake ini zvekutsanya ndombomira uye maTen days acho itaimoga! (if this year's ten days prayer and fasting letter insists that we should pray for Mugabe and his ZANU-PF government, I'm not going to fast and pray this year).' (Anonymous Kuwadzana ZAOGA District Church member) (Interview: Anonymous Kuwadzana ZAOGA District church member, 26 Years, Male, 19/12/2020)

Again, for Apostle Guti to keep his church from splitting, during Prophet Andrew Wutawunashe's time as President of the Evangelical fellowship of Zimbabwe (EFZ), Apostle Guti and his church, ZAOGA, left the organisation and re-joined the Zimbabwe Council of Churches (ZCC), citing the partisan attitude that the organisation was now exhibiting (Togarasei 2006:224). Prophet Wutawunashe, as the President of the EFZ, had come out openly as a supporter of the ZANU-PF party and worked closely with the party. As a result, Wutawunashe was regarded as a ruling party collaborationist by some members of his church. Wutawunashe would often be seen praying at national events such as the independence celebrations. As if that was not enough, Wutawunashe endorsed the presidential election results of 2002 as the will of God, and he openly supported the controversial land reform programme the ruling party introduced in 2000. However, Apostle Guti did not want it to be so apparent that he was pro-ZANU-PF. Thus, Apostle Guti withdrew from the EFZ and joined the Zimbabwe Council of churches. To authenticate that his moving from EFZ during Prophet Wutawunashe's tenure was Apostle Guti's political camouflage, after the lapsing of Prophet Wutawunashe tenure as the EFZ President, the ZAOGA bounced back to the EFZ.

Arguably, the deletion of the phrase 'praying for Mugabe and the ZANU-PF government 'from the Ten-days letters from 2002 to 2020 and the moving out from the EFZ was not a positive sign of the regaining of a prophetic voice within this Pentecostal movement. The reason for this submission is that Apostle Guti, like other Zimbabwean Pentecostal Church leaders, did not come out openly to condemn the political violence perpetrated by the ZANU-PF government during Mugabe's tenure and even after Mugabe. Thus, it is the author's view that the Zimbabwean Pentecostal movement sacrificed its prophetic voice by not condemning the August 2018 killing of ordinary civilians by the Zimbabwean army over a disputed presidential result. Instead, on 26 January 2020, A postle Guti received President Emmerson Mnangagwa and gave him a platform to address men and women of the collar who had come all the way from different continents for a spiritually deeper life conference. Perhaps President Mnangagwa had imposed himself on the conference, but it confirmed the continuous political conniving of the church leader. In his address, Mnangagwa confirmed that the church leader had intimated to him that the church prays religiously for the state President and his ZANU-PF government every first day of the first 10 days of January (Mpofu, 2020) even though the Ten-days letters since 2000 were no-longer stating that people should pray for the President and the ZANU-PF government. Accordingly, it is against this background that the presence of President Mnangagwa at this leadership summit underscores the church leader's motive with regard to setting the politics of the agenda. Thus, this article has argued that the traits we find in the Old Testament prophets such as Ahijah, Elijah, Amos and Jeremiah as spokespersons of God in all spheres of life (Vengeyi 2010) are absent amongst most Zimbabwean Pentecostal Church leaders. From the given discussion, it can be noted that a prophet should not be intimidated by selfish, unjust and ruthless politicians. A prophet must offer a critical analysis of the problems besetting his/her society in order to offer solutions, which may not always be in favour of the rich and rulers.

Thus, so far, this article has discussed Apostle Guti and politics in Zimbabwe. What remains is to discuss briefly how 
other Pentecostals churches in Zimbabwe have navigated politics. Accordingly, the following section discusses the broader debate on whether other Zimbabwean Pentecostal leaders are truly detached from party politics or are they fully involved, but mutating - taking different shapes to hide their political identities. This will help to conclude whether ZAOGA, as a case study, has either confirmed or challenged the current pattern of Pentecostalism and party politics in Zimbabwe.

\section{Spiritualised political theology in other Zimbabwean Pentecostal churches}

Whilst Apostle Guti's spiritualised theology on politics was highlighted as a major setback for the church leader becoming the voice of the voiceless, this article also posited that many other Zimbabwean Pentecostal church leaders have propagated the same theology. For instance, as highlighted elsewhere in this article, Prophet Andrew Wutawunashe of the Family of God Church was a close associate of the ZANU-PF party (Togarasei 2006) at one time, and could not speak against ZANU-PF. However, the same Wutawunashe, who professed that President Mugabe was chosen by God, in 2017, after the coup, reversed his statement:

I admitted that God elected Mugabe to finish his race, just like Moses, who handed over his work to Joshua. I talked from a spiritual point of view, but, in the end, that is not what happened. The country was not developing, rather, they were having factional wars. I commend the Zimbabwe Defence Forces for the wisdom they applied in midwiving a peaceful transition in the governance of our nation, Zimbabwe. (Ndlovu \& Mwanaka 2017)

Even the emerging crop of Pentecostal leaders such as Uebert Angel and Emmanuel Makandiwa have not shown a willingness to engage the governing authorities on issues of governance (Togarasei \& Biri 2018). They seem to be too busy directing people regarding how to be rich without addressing the socio-political and economic structures that keep many of the Zimbabweans in servitude (Togarasei \& Biri 2018).

Accordingly, this study has argued that the Zimbabwean Pentecostal movement, in particular, has done little so far to bring a democratic change in the country at large for which it has been waiting for a long time. Perhaps the rise of Pentecostal church founders such as Apostle Talent Chiwenga who is regarded by his fellow Pentecostal Church leaders as a controversial street preacher will bring a change and restore the prophetic voice within the Zimbabwean Pentecostal Christianity. Apostle Chiwenga has publicly denounced activities of state-sponsored violence in the country on many occasions. Arguably, although one cannot present evidence that abductions of opposition party members are state sponsored, the argument that remains is why does the ZANU-PF government condone such activities?

\section{Conclusion}

What has been highlighted in this article is Apostle Guti's continuous political subterfuge as displayed in his pastoral letters to his church. At first, Apostle Guti's political ideology was that the church has nothing to do with politics. The main reasons for this apolitical position were the church's eschatological emphasis that this world is not our home; heaven is our home. In addition, the church espouses a theology which emphasises that this world is evil and is controlled by the devil. It is on this note that Apostle Guti was quoted saying 'let the devil do his work and us doing our work'. However, this article noted that this position changed in the dawn of 1990s when the church had grown and was in need of land to build centres of worship, amongst other material things. On that note, the church openly supported ZANU-PF regardless of how corrupt ZANU-PF was. Again, at the dawn of 2000, with the rise of the MDC, this article revealed that ZAOGA continued with its political subterfuge. Again, this political subterfuge was demonstrated by the deletion of the phrase 'praying for our President Robert Gabriel Mugabe', although the late Mugabe was still the President of the country. We found out that the removal of that phrase was necessitated by the brutality of ZANU-PF. However, because of a spiritualised political theology espoused within this Zimbabwean Pentecostal movement, the church continued to invite ZANU-PF officials to their church gatherings and allowed them to address congregants.

Therefore, it is the considered view of this author that, if the Zimbabwean Pentecostal movement is to reclaim its prophetic role, there is a need for Pentecostal church leaders to come out of their hiding places by disengaging from party politics and becoming the voice of the voiceless. Prophets such as Ahijah, Elijah, Amos and Jeremiah have been cited as testimony to the fact that a prophet should be a spokesman of God in all spheres of life. Consequently, a prophet should be prepared to face the negative responses of the rulers when they are upset by criticism. Accordingly, unless and until the Zimbabwean Pentecostal church leaders decide to risk being unpopular with the political leaders of the day and taking a principled stand to correct the political irregularities in the land, the Pentecostal movement will remain insignificant with regard to the democratisation agenda.

\section{Acknowledgements}

The author wishes to thank Prof Andries van Aarde, the editors, of HTS, the anonymous peer reviewers and the AOSIS team for their invaluable work and suggestions.

\section{Competing interests}

The authors have declared that no competing interests exist.

\section{Authors' contribution}

I declare that I am the sole author of this research article. 


\section{Ethical considerations}

This article followed all ethical standards for carrying out research without direct contact with human or animal subjects.

\section{Funding information}

This research received no specific grant from any funding agency in the public, commercial or not-for-profit sectors.

\section{Data availability}

Data sharing is not applicable to this article as no new data were created or analysed during this study.

\section{Disclaimer}

The views and opinions expressed in this article are those of the authors and do not necessarily reflect the official policy or position of any affiliated agency of the authors.

\section{References}

Biri, K., 2012, 'The silent echoing voice: Aspects of Zimbabwean Pentecostalism and the quest for power, healing and miracles', Studia Historiae Ecclesiasticae 38(2), $1-12$.

Biri, K., 2013a, 'African Pentecostalism and politics in post-colonial Zimbabwe: A comparative critique of the leadership styles of Ezekiel Guti and Robert Mugabe' in E. Chitando (ed.), Prayers and players: Religion and politics in Zimbabwe, pp. 111-124, Sapes, Harare.

Catholics in Coalition for Justice and Peace (CCJP), 1997, The Catholic Commission for justice and peace in Zimbabwe and the legal resources foundation, pp. 1-26, Mambo Press, Gweru.

Gunda, M.R., 2014, 'African "Biblical" Christianity: Understanding the "spirit-type" African initiated churches in Zimbabwe', in E. Chitando (ed.), Multiplying in the spirit: African initiated churches in Zimbabwe, pp. 145-160, University of Bamberg Press, Bamberg.
Gunda \& Mtetwa, 2013, 'The Bible as a political resource in Zimbabwe: The subtleness of biblical teachings in Zimbabwean politics', in E Chitando (ed.), Prayers and players: Religion and politics in Zimbabwe, pp. 159-176, SAPES, Harare.

Gundani, P., 2008, 'Prophecy, politics and power: Changing relations between the Catholic Church and the Zimbabwean State (1980-2007)', Studia Historiae Ecclesiasticae 53(9), 1689-1699. https://doi.org/10.1017/СBO9781107415324.004

Guti, E.H., 1994, The church and political responsibility: Responsibility and resources management preparation for the next generation, EGEA Publication, Harare.

Guti, E.H., 2014, History of ZAOGA forward in faith: The book of remembrance: How it began and where it is going, 5th edn., EGEA Publications, Harare.

Guti, E.H., 2015, 'Tsamba Dze Mazuva Gumi Dzegore Ne Gore: Matsamba Nezvokunamatira Volume 1, 1975-2000', EGEA Publications, Harare.

Kgatle, M.S., 2018, 'The prophetic voice of the South African council of churches: A weak voice in post-1994 South Africa', HTS Teologiese Studies/Theological Studies 74(1), 1-8. https://doi.org/10.4102/hts.v74i1.5153

Maxwell, D., 2000, 'Catch the cockerel before dawn: Pentecostalism and politics in post-colonial Zimbabwe', Journal of the International African Institute 70(2), 249-277. https://doi.org/10.3366/afr.2000.70.2.249

Maxwell, D., 2006, African gifts of the spirit: Pentecostalism \& the rise of Zimbabwean transnational religious movement, Ohio University Press, Ohio.

Mushonga, M., 2009, History:The catholic commission for justice and peace (CCJP) and the struggle for democratization in rhodesia (Zimbabwe) 1972-1980, pp. 75-91, A journal of Contemporary Research, Lwati.

Ndlovu and Mwanaka 2017, 'The birth of a new era: Wutawunashe', NewsDay, viewed 22 September 2020, from https://www.newsday.co.zw/2017/11/birth-new-erawutawunashe/.

Nell, I., 2009, 'In search of meaning: Moving from the prophet's voice to prophecy in community; A South African perspective', Scriptura: International Journal of Bible Religion and Theology in Southern Africa 102(1), 562-578. https://doi.org/ 10.7833/102-0-615

Togarasei, L., 2006, 'The birth of a prophet: Andrew Wutawunashe's break from the reformed church', Brill 35(2), 215-225. https://doi.org/10.1163/15725430 6776525717

Togarasei, L., 2013, 'Pentecostal churches and politics in Zimbabwe's turbulent years (2000-2008)', in E. Chitando (ed.), Prayers and players: Religion and politics in Zimbabwe, SAPES, Harare, pp. 165-177.

Togarasei, L. \& Biri, K., 2018, 'Pentecostal churches: Money making machines or purveyors of socio-economic growth?', in. L. Togarasei (ed.), Aspects of Pentecostal Christianity in Zimbabwe, Chapter 12, pp. 165-177, Springer, Cham.

Vengeyi, O., 2010, 'Israelite prophetic marks among Zimbabwean men of God: An evaluation of the conduct of selected Zimbabwean church leaders in recent politics', Exchange 39(2), 159-178. https://doi.org/10.1163/016627410x12608 581119795

Vengeyi, O., 2013, 'Zimbabwean Pentecostal Prophets: Rekindling the "true and false Prophecy" debate', in R.M. Gunda \& J. Kugler (eds.), Prophets, profits and the Bible in Zimbabwe, pp. 29-54, 12th edn., University of Bamberg Press, Bamberg. 